University of Arkansas, Fayetteville

ScholarWorks@UARK

Education Reform Faculty and Graduate

Students Publications

Education Reform

$3-11-2019$

\title{
A Longitudinal Analysis of Volunteerism Activities for Individuals Educated in Public and Private Schools
}

\author{
Albert Chang \\ University of Arkansas, Fayetteville \\ David Sikkink \\ University of Notre Dame
}

Follow this and additional works at: https://scholarworks.uark.edu/edrepub

Part of the Educational Assessment, Evaluation, and Research Commons, Educational Methods Commons, and the Secondary Education Commons

\section{Citation}

Chang, A., \& Sikkink, D. (2019). A Longitudinal Analysis of Volunteerism Activities for Individuals Educated in Public and Private Schools. Education Reform Faculty and Graduate Students Publications. Retrieved from https://scholarworks.uark.edu/edrepub/73

This Article is brought to you for free and open access by the Education Reform at ScholarWorks@UARK. It has been accepted for inclusion in Education Reform Faculty and Graduate Students Publications by an authorized administrator of ScholarWorks@UARK. For more information, please contact scholar@uark.edu. 


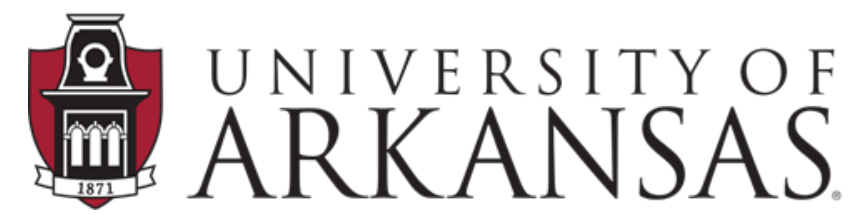

College of Education \& Health Professions Education Reform

\title{
WORKING PAPER SERIES
}

\section{A Longitudinal Analysis of Volunteerism Activities for Individuals Educated in Public and Private Schools}

\author{
Albert Cheng \\ University of Arkansas \\ David Sikkink \\ University of Notre Dame
}

February 15, 2019

EDRE Working Paper 2019-06

The University of Arkansas, Department of Education Reform (EDRE) working paper series is intended to widely disseminate and make easily accessible the results of EDRE faculty and students' latest findings. The Working Papers in this series have not undergone peer review or been edited by the University of Arkansas. The working papers are widely available, to encourage discussion and input from the research community before publication in a formal, peer reviewed journal. Unless otherwise indicated, working papers can be cited without permission of the author so long as the source is clearly referred to as an EDRE working paper. 


\begin{abstract}
Previous studies offer evidence that U.S. public and private high schools differentially influence volunteerism in adolescence. However, these studies are typically cross-sectional and only consider whether the individual volunteered or not. We address patterns of volunteering from adolescence into adulthood and the kind of volunteering activity in which individuals engage. We also theorize that distinctive civic values within public and private schools together with their respective organizational ties to other civic organizations channel students into particular volunteering activities. Relying on a longitudinal, nationally-representative sample of U.S. adolescents, we track volunteering from adolescence into young adulthood and identify the types of volunteering activities in which respondents engage. Results demonstrate that the likelihood of volunteering changes through the life course, and students from different schooling backgrounds systematically sort into specific volunteering activities as our theories predict. Keywords: Volunteerism, Religious Schools, Civic Values, Young Adulthood
\end{abstract}


A Longitudinal Analysis of Volunteerism Activities for Individuals Educated in Public and Private Schools

The apparent decline in quantity and quality of civic participation in the U.S., particularly among youth and young adults, has generated calls for renewed attention to civic education (Bureau of Labor Statistics, 2016; Grimm et al., 2006; Putnam, 2000; Smith et al., 2009). This call begs the question of whether and how civic education in secondary schools matters for civic engagement during adolescence and into young adulthood. In light of this, some research has explored the impacts of civic education programs on civic participation (Astin et al. 1999; Campbell \& Niemi, 2016; Henderson et al., 2012; Planty et al., 2006; Riedel, 2002). A second strand of research focuses on civic outcomes in private schools, investigating whether these schools strengthen or weaken civic engagement and values, given concerns that they may not necessarily share the civic mission of public schools to prepare students for common life (Campbell, 2001; Cheng, 2014; Fleming et al., 2014; Marks \& Kuss, 2001; Smith \& Sikkink 1999; Wolf, 2007).

Yet significant research gaps in both of these lines of research remain. Compared to what is known about student civic engagement during high school, the longer-term impact of adolescent experiences on adult civic engagement is less well understood. Some research argues that student government participation and student volunteering during high school has a positive effect on adult voting, subsequent volunteering, and other forms of civic engagement (Gill, et al., 2018; Hart et al., 2007; McFarland, 2006; Planty et al., 2006). But not all studies find consistent associations between high school experiences and adult civic engagement (Henderson et al., 2012; Jones \& Hill, 2003). Studies of the role of school sector in shaping adult civic engagement have also produced mixed results. Private school graduates are sometimes more likely to be 
civically engaged after secondary school than public school graduates (Wolf, 2007); in other cases, they are not (Dill, 2009; Fleming et al, 2014; Marks \& Jones, 2004; Hill \& den Dulk, 2013; Sikkink, 2012). The research literature has also not explored connections between school experiences and particular types of civic involvement. That is, researchers have studied factors that influence the propensity to volunteer but have not widely considered which specific types of civic organizations and causes individuals commit to nor why they commit to them.

In this paper, we address these research gaps by painting a detailed picture of volunteerism using longitudinal data to observe trends and specific volunteer activities among a nationally-representative sample of U.S. individuals from adolescence through young adulthood. As with other research in this area, our ability to draw causal inferences between student volunteering and schooling is hampered by a lack of an experimental design and detailed measures of school-level characteristics, especially regarding their civic organizational networks. We instead present a theoretical case for differences in civic education between Catholic, Protestant, secular private, and public schools and subject our hypotheses to an empirical test.

We primarily propose that the organizational networks of these schools and the civic values that they espouse - factors not widely considered in the civic education literature uniquely shape the types of civic organizations and causes taken up by their students from adolescence to early adulthood. Analysis of our data reveals distinctive volunteering patterns across the separate school sectors that are consistent with what our theories would predict. Identifying the particular types of volunteering activities in which individuals participate and exploring reasons behind these patterns are valuable for better understanding the nature of civic engagement broadly.

\section{Literature Review}




\section{Theories of School Sector and Civic Engagement}

Civic formation processes are complex, especially when considering the influences of youth experiences on longer-run adult civic engagement. Although there are a variety of civic outcomes such as voting or civic knowledge, we focus on volunteering defined as freely choosing to give one's time and effort to support the work of a charity or other formal organizations without material compensation (Snyder \& Omoto, 2008). Rather than testing the efficacy of a specific program or curriculum, as much of the prior research has done (Campbell \& Niemi, 2016; Planty et al., 2006), we focus on the influence of more general social dynamics and cultures within school communities. We theorize that expectations, habits, and practices related to civic involvement shape the formation of volunteering identities. Institutional ties between particular school communities and other civic organizations, whether they are established through familiarity, personal relationships, or positions in recruitment networks, also influence the propensity to volunteer (Jones \& Hill, 2003; Marks \& Jones, 2004; Omoto \& Snyder, 2002; Snyder \& Omoto, 2008).

Specifically, we develop theories about public schools and the three dominant types of private schools in the U.S. - Catholic, Protestant, and nonreligious — with respect to student volunteering and community service, explaining how civic socialization in each respective schools should influence student commitments and practices related to volunteering. Civic socialization in schools depends on numerous factors that characterize the school community: school mission and authority, curriculum and pedagogy, social capital, and organizational networks between schools and civic organizations. The wide variation in these institutional characteristics across public, Catholic, Protestant, and nonreligious schools is well documented in the research literature (Campbell, 2001; Cheng, Trivitt, \& Wolf, 2016; Bryk, 1993; Mehta \& 
Fine, 2019; Uecker, 2009). By taking a comparative approach that highlights key differences in across these types of school institutions, we shed light on school characteristics and processes that influence civic engagement of students over time and the various types of organizations for which the students volunteered.

Public schools. Public schools in the U.S., emerging out of the strong relationship between local communities and mid-19th century Protestantism, originated with a mission to form citizens for effective participation in democracy. At different points in history, civic education in public schools was driven by a concern to socialize and assimilate immigrants, especially Catholics, but on the whole the public school civic mission reflected the integral place of these schools in the life of the local community (Glenn, 2012). As highly visible institutions in communities, public schools are likely to continue to have a central place within the local civic ecology. While civic organizations attempt to reach needy families and children through public schools, schools attempt to link students to community service opportunities through the school's ties to civic organizations.

The civic location of public schools together with longstanding concerns about separation of church and state may produce general patterns in volunteering that favor involvement in the nonreligious civic sphere (Justice \& Macleod, 2016). For instance, a public school is more likely to form an organizational tie to the United Way rather than Catholic Relief Services—an overtly religious organization. To the extent that public schools provide frameworks for understanding civic obligations, prepare students for democratic participation, or channel students to organizations with established ties to the school, public-school students would be more likely to be involved in civic organizations and causes that are in similar positions in civic space as their 
schools. These organizations especially include nonreligious organizations such as political and community-service groups that are local or even based within the school (Giles \& Eyler 1994).

A democratic governance structure that positions public education in relation to various political groups and forces (Moe, 2011) may also contribute to stronger bridges between public schools and political volunteering. We would similarly expect a natural connection to environmental causes and organizations, since this involvement is closely linked to the political sphere. Moreover, the environmental cause fits well with the civic mission of public schools, since recycling, conservation, and other environmental causes embed a moral dimension, a civic responsibility and obligation, without drawing directly on religious themes and motives (Chawla \& Cushing, 2007).

We expect that public schools instill civic skills that influence students to continue volunteering beyond high school as well. This impact may be due to formal civic education found in the public school curriculum or related service-learning opportunities, though the effect likely diminishes over time (Campbell \& Niemi, 2016; Hill \& Jones, 2003; Marks \& Kuss, 2001; Planty et al., 2006). A school that fosters volunteering during the high school years may form volunteering identities, enhance civic skills, and create ties to civic organizations that may continue to facilitate volunteering during college or in early career and family life. But changing contexts across the life course, such as college, career, or family life, raise potential obstacles to the long-reach of high school experiences and socialization. Thus, despite decreases in overall rates of volunteering, we suspect that the kind of volunteering performed does not change drastically as adolescents enter young adulthood. Organizational ties established during high school, especially particularly toward volunteering in the political, environmental, nonreligious civic sector, may continue to shape volunteering into young adulthood (Sikkink, 2012). 
Catholic Schools. The religious mission of service to humanity generates strong cultural supports for volunteering in post-Vatican II Catholic schools. This is reflected in schooling practices, including an emphasis on integrating volunteering and civic engagement directly into classes (Bryk et al. 1993; Campbell, 2001; Marks \& Kuss, 2001; Scanlan, 2008). Catholic schools have organizational networks that facilitate student volunteering and community service, particularly to areas of civic life where Catholic organizations are well-represented. These opportunities include Catholic Relief Services, Catholic hospitals, and other civic institutions that are religious in orientation and mission. These organizations are often active in health care and poverty relief. Student volunteering through Catholic churches and church-related organizations is also likely common given that such activity is constitutive of the overlapping social capital that binds home, school, and parish together (Bryk et al., 1993; Campbell, 2001; Degeneffe, 2003).

Explicitly religious instruction and ties to Catholic civic organizations might sustain volunteering in poverty relief, international, and health care organizations and causes among Catholic-school students (Planty et al., 2006; Scanlan, 2008). Moreover, since Catholic civic organizations have an interest in seeking out Catholic school graduates, which constitute a ready pool of volunteers, it seems more likely that the organizational ties to Catholic civic organizations would have staying power into young adulthood.

Yet the effectiveness of ties to Catholic dioceses and parishes, built in part through Catholic school experiences, are difficult to judge. Catholic parishes are generally not as effective in maintaining levels of commitment and involvement of young adults compared to Protestant churches (Smith et al., 2014). Though ties to Catholic schools or parishes experienced during high school likely channel a good deal of Catholic student volunteering through Church 
activities, the impact of this tie on Catholic student volunteering may attenuate after high school graduation. Nonetheless, if Catholic schools focus on fostering commitment to particular volunteer activities, such as health care and poverty relief, one might observe higher rates of volunteering among adults who attended Catholic school in those areas but not overall.

Protestant Schools. Protestant schools are typically marked by a robust, tight-knit school community and a strong sense of belonging and collective identity, binding students to the mission and socialization goals of the school. Even while formal ties to a particular congregation are decreasing in favor of independent school boards and nondenominational evangelical schools, conservative Protestant schools no doubt maintain strong organizational ties to local evangelical churches, in part as a strategy of student recruitment and as an effort to form students through cooperation and consistency across home, church, and school. Consistent with the average levels of involvement in bridging civic organizations of conservative Protestant churches, we expect that ties to other civic organizations, whether nonreligious or Catholic, are not strong among Protestant schools (Beyerlein \& Hipp, 2006). Student volunteering may be funneled into and through religious congregations and other religious organizations active in civic life given the lack of ties between Protestant schools and the nonreligious civic sphere. In contrast to Catholic schools, which tightly link spiritual formation and civic commitment and activity, Protestant orientations to spiritual formation in schools may not have a natural fit with volunteering outside the religious or school community.

Insofar as Protestant schools shape the pattern of civic volunteering, they are likely to facilitate or to encourage students toward international relief efforts, since these schools are connected to and directly organize overseas mission trips that include social service volunteering. These trips have been associated with subsequent civic involvement in religious 
organizations (Beyerlein et al., 2011). In addition, connections to civic organizations that have a religious orientation, such as Habitat for Humanity, may be stronger within Protestant schools and may prepare students for involvement in similarly religiously-affiliated community and neighborhood improvement organizations later in life. We generally expect that the kind of volunteering that is encouraged within the cultural-structural environment of Protestant schools is focused on meeting human needs directly, such as poverty relief, the needs of the elderly, and perhaps health care services (Schwartz \& Sikkink, 2017; Sikkink, 2012; Wuthnow, 2009).

Strong ties to those types of volunteering activities may steer Protestant-school students away from other types of volunteering, such as those for political and environmental purposes. Civic volunteering focused on structural issues, especially related to political issues outside of pro-life causes, are not common among evangelical churches (Beyerlein \& Chaves, 2003), and this may be replicated within Protestant schools. Socialization messages in these schools focus on pursuing a religious calling and eschewing secular, worldly values, which generally refers to dominant cultural orientations toward money and power (Sikkink, 2014). Conceptions of politics as the self-interested pursuit of power, common in evangelical circles, set up conflicts between political engagement and the religious identity formation goals of the school. Some political groups, such as environmentalists, have found conflict with conservative religious views and groups, thereby reducing the likelihood of recruitment efforts and organizational ties to Protestant schools (Evans \& Feng, 2013; Schwartz \& Sikkink, 2017).

Student patterns of volunteering established in Protestant schools may persist into young adulthood because these schools instill religious commitments to meet direct human needs through personal sacrifice. That may continue to guide Protestant students in adulthood toward the kind of civic engagement they experienced in high school, such as community or 
neighborhood involvement in organizations like Habitat for Humanity, or other poverty relief and international social service organizations. The dominant way that Protestant schools shape adult civic engagement may be through enhancement of ties and commitments to religious congregations, which is both encouraged as a norm within evangelical schools and facilitated through numerous organizational ties between evangelical schools and congregational activities (Planty et al., 2006). In contrast to Catholic school students, for whom commitment and membership to local parishes lower (Smith et al., 2014), Protestant school students should be more likely to organize their volunteering through churches or church-related organizations in young adulthood (Schwartz \& Sikkink, 2017). This difference between Catholic and Protestant school students is widened by the greater religious diversity in Catholic schools, which makes it more difficult for them to maintain civic volunteering through religious organizations for all their graduates (Cheng et al., 2016).

Indeed, prior research suggests that higher volunteering rates among Protestant school students relative to their public school counterparts during secondary school persists into adulthood, while adults who attended Catholic schools are not any more or less likely to volunteer than are adults who attended public schools (Dill, 2009; Hill \& den Dulk, 2013). It is important to note, however, that this research does not test whether ties to religious congregations explain this pattern. Later, we test whether Protestant school students are more likely to maintain bridges to civic organizations that are religiously affiliated, which may be generated in part through involvement in evangelical congregations.

Nonreligious Private Schools. Nonreligious private schools are difficult to assess on civic engagement, given the relatively wider diversity in the sector. On one hand, the nonreligious private school sector comprises schools that operate in the Progressive tradition. 
These schools typically uphold a sense of civic purpose and obligation, which mobilizes students into community-oriented, political, and poverty relief causes and organizations (Broome, 2011; Dahlin, 2010). These dispositions will likely persist into adulthood, similar what we have hypothesized about the public school student.

On the other hand, many nonreligious private schools are primarily oriented to admission to elite colleges and universities and may encourage their students to pursue volunteering opportunities to gain leadership experience and yield a favorable a college admission application (Handy et al., 2010; Marks \& Jones, 2004). An individualistic orientation to the school and competitive school climate may enhance an instrumental orientation to volunteering during high school (Campbell, 2001). Such an environment is unlikely to generate the kind of volunteer identities and commitments that would lead to higher levels of volunteering into young adulthood. To the extent that an increase in volunteering during high school is a strategy to gain admission to an elite college or university, nonreligious private schoolers would be unlikely to maintain civic engagement outside the structural supports of college or career. Moreover, unlike religious private schools, nonreligious private schools — whether elite or Progressive — may also lack natural and well-worn pathways between school and most religious organizations operating in the civic sphere that would sustain volunteering in such organizations into adulthood.

\section{Summary and Research Hypotheses}

The organizational locus and values of each school sector in the civic sphere should not only influence a general propensity to volunteer but also funnel students into particular types of volunteer activities in adolescence and into young adulthood. 
H1: Catholic school experiences increase the likelihood that students will volunteer in civic sectors in which Catholic organizations are well-represented, such as health care and community centers. Organizational connections from Catholic schools to their parishes and dioceses and other religious organizations in the civic sphere should enhance volunteering for church or church-related organizations, but this may be generated by the direct connection between Catholic schools and parishes, and therefore not extent beyond high school.

H2: The volunteerism among Protestant high school students will primarily be driven by service generated in and through religious organizations both in adolescence and into young adulthood. Moreover, the emphasis on obligations to meeting human needs directly rather than through structural change should be associated with greater involvement in community or neighborhood organizations and poverty relief organizations rather than political or environmental organizations.

H3: Experiences in nonreligious private schools as well as public schools should particularly enhance volunteering in nonreligious organizations, especially in environmental groups, political organizations, and service organizations based within the schools or the surrounding community.

\section{Methodology}

\section{Data}

We use data from the Education Longitudinal Study of 2002 (ELS:02) to examine volunteerism rates for students with different schooling backgrounds. ELS:02 consists of surveys administered in four waves by the US Department of Education to over 15,000 US tenth-graders. Respondents were initially surveyed in 2002 and given follow-up surveys in 2004, 2006, and 
2012. This data provides longitudinal information about US adolescents as they progress through secondary education and move into post-secondary education and adulthood. Stratified random sampling procedures were used to select schools and respondents to ensure that the data are nationally representative of all tenth-graders. Teachers, parents, and school administrators also provided additional information about the respondent's background and school setting in the initial year of the survey. ${ }^{1}$

Students in the sample are asked about a series of items, including their family life, future aspirations, school experiences, employment outcomes as well as their demographic background. We use information that respondents provided about their volunteering activities. In each survey wave, respondents were asked whether they have participated in community service within the last two years. In the second through fourth waves, respondents who volunteered also indicated where they completed their volunteering: youth or community service organizations (e.g., Scouts, Little League, Big Brothers Big Sisters, Key Club or other similar school-based service groups); political clubs or organizations, religious groups (not including volunteering at worship services); community centers or neighborhood improvement organizations; hospitals or nursing homes; or recycling, conservation, or environmental organizations. Table 1 provides rates of volunteering through these organizations for each wave and overall for each wave. Respondents may have volunteered through more than one of these organizations. We point out that volunteerism rates peak during the respondents' twelfth-grade year and decrease into young adulthood and that most volunteering occurs in youth or community-service organizations, churches, and community centers.

\section{«Table 1 Here»}

\footnotetext{
${ }^{1}$ For further information about ELS:02, please see Ingels et al. (2014).
} 
The ELS:02 data set also allows us to identify the type of high school that each respondent attended, our key independent variable. As shown in Table 2, about 92 percent of respondents attend public high schools. Four percent of respondents attend Catholic high schools while about 2 percent of respondents attend Protestant ${ }^{2}$ and non-religious high schools, respectively. The remainder of Table 2 lists summary statistics for other demographic characteristics of the respondent, such as gender, race, school characteristics, mother's educational attainment, family income, educational attainment, and cognitive skills in mathematics and reading.

\section{Empirical Strategy}

We run a series of logistic regressions to explore patterns between secondary schooling background and volunteerism behavior. Because we are interested in the types of activities that volunteers participate in, we limit the sample to respondents who reported some form of volunteering in each wave. We then examine the rates at which respondents participate in a particular type of volunteering work at each wave of the study, comparing them across students who attended public, Catholic, Protestant, and nonreligious high schools. We estimate the following model:

$$
V_{i}=\beta_{0}+\boldsymbol{\beta}_{1} \boldsymbol{S}_{i}+\boldsymbol{\beta}_{2} \boldsymbol{X}_{i}+\epsilon_{i}
$$

In equation $1, V_{i}$ is an indicator for whether participant $i$ completed a specific type of volunteer work $^{3}$ within the last two years of the respective ELS wave. $\boldsymbol{S}_{i}$ is a vector of indicators for school

\footnotetext{
${ }^{2}$ Schools that we refer to as Protestant schools are coded as non-Catholic religious private schools in the original data. Undoubtedly, this group of schools also includes a small sample of schools of other religious traditions. Data from the US Department of Education (2012), however, indicate that 94 percent of all non-Catholic religious private schools were Protestant schools in 2002. Due to the small proportion of schools from non-Protestant religious traditions and our inability to distinguish them from Protestant schools, we refer to these schools as Protestant schools throughout the manuscript.

${ }^{3}$ It is possible that certain respondents engaged in multiple types of volunteering activities. One could model unique combinations of volunteer activities, but we are unable to do so in this analysis as some cell sizes became too small and unique to reveal meaningful patterns.
} 
type, that is, Catholic, Protestant, or nonreligious school with public school as the omitted category. Finally, $\boldsymbol{X}_{i}$ is a vector of the control variables listed in Table 2, and $\epsilon_{i}$ is the usual error term clustered at the school level to account for the school-based sampling strategy of ELS:02. All estimates use sampling weights so that results are generalizable to a nationally representative sample of individuals who were U.S. tenth-graders in 2002.

\section{«Table 2 Here»}

\section{Results}

\section{Overall Volunteerism Rates over Time}

We begin by presenting overall volunteerism rates over time by school sector. Figure 1 displays the estimated probabilities, with 95 percent confidence intervals, of participating in volunteer work for respondents in a given school sector, net of the control variables included in Table 2.

\section{«Figure 1 Here》}

During the respondents' tenth-grade year, students in Catholic schools are most likely to participate in volunteer work in tenth grade. Over 40 percent of respondents who attended Catholic schools in tenth grade state that they have completed volunteer work, while less than one third of respondents from Protestant and public schools report doing the same. These differences are substantively large and statistically significant at the 0.05 level as indicated by the non-overlapping 95 percent confidence intervals. Volunteerism rates are similar among Protestant, non-religious private, and public school students.

By 12th grade, volunteerism rates rise for all sectors with respondents attending Catholic and Protestant schools leading the way, perhaps indicating a tendency for high schools to require or provide volunteering opportunities for older students. About 70 percent of students in 
religious schools report completing volunteer activity within the last two years while 58 percent of public-school students report the same, a difference that is statistically significant at the 95 percent confidence level. Meanwhile, about 63 percent of students in nonreligious private schools report volunteering in 12th grade.

Volunteerism behavior across all school sectors decreases during the postsecondary years. Half of the students from Protestant high schools report having completed volunteer work since their twelfth-grade year. Meanwhile, the rate for students in the other school sectors stands lower at about 40 percent. The drop in volunteerism rates is most pronounced for respondents from Catholic high schools, who are 6 and 12 percentages points less likely to volunteer than respondents from public and Protestant high schools, respectively. Both differences are statistically significant at the 0.05 level. Volunteerism rates for students who attended nonreligious private schools are similar to rates for students who attended public schools.

Finally, volunteering rates observed in the final wave of data collection are similar to those observed in the previous wave six years earlier in Wave 3. Students who attended Catholic, nonreligious private, and public schools still have volunteer rates of about 40 percent. Rates for students who attended Protestant secondary schools remain the highest at 45 percent. However, none of the rates across all school sectors are statistically distinguishable.

\section{Types of Volunteering}

We now turn to results that examine the type of volunteering activity in which respondents participate over time. Results for each wave of ELS:02 are presented in Table 3. We reiterate that these models are restricted to respondents who reported some volunteering in the respective wave because the aim is to describe the kinds of activities respondents do conditional on volunteering. The three panels in Table 3 show where students from each school scector 
volunteered during the twelfth-grade year, two years after twelfth grade, and eight years after twelfth grade, respectively. Estimated coefficients represent the likelihood of participating in a given type of volunteering activity as marginal changes in probability relative to public-school students, who comprise the omitted category. No results are available for Wave 1 data because respondents were not asked the type of volunteering work that they completed in that data collection.

\section{$<<$ Table 3>>}

Catholic School Students. We begin by describing patterns for Catholic-school students. Despite having much higher overall volunteering rates than public-school students, Catholicschool students were about 4 percentage points less likely to volunteer in political organizations, but were 6 and 4 percentage points more likely to volunteer in hospitals and community centers, respectively. As shown in the second panel, two years after the twelfth-grade year, Catholicschool students are no different from public-school students in terms of the kinds of volunteering activities in which they participate. In other words, along with the overall drop in volunteering rates among Catholic-school students (Figure 1), the higher rates of volunteering in hospitals and community centers that were observed during high school decrease among those who volunteer. Finally, little change is observed eight years after high school among Catholic-school students. The only exception is suggestive evidence that volunteers from Catholic-school students are about 3 percentage points more likely serve through hospitals, relative to public-school students.

Protestant-School Students. During high school, Protestant-school students are 4 percentage points less likely to volunteer in political organizations and 12 percentage points less likely to volunteer in youth or community-service organizations, relative to public-school students. Otherwise the kinds of activities that these students participate in are similar. However, 
we begin observing a greater divergence in the postsecondary and young adult years. Two years after high school, Protestant-school students become more likely to volunteer through religious organizations and less likely through community centers and environmental groups, relative to public school students. Protestant-school students are 13 percentage points more likely to volunteer through religious organizations and 7 to 9 percentage points less likely to volunteer in community centers and environmental groups, respectively. This distinction continues to persist 8 years after high school, although the lower likelihood of volunteering in community centers dissipates. On the other hand, the lower likelihood of volunteering in political clubs among Protestant school-students relative to public-school students - a difference of 5 percentage points — becomes substantively and significantly significant.

Nonreligious Private School Students. Turning to nonreligious private schools, we first point out that we do not observe any differences in volunteerism activity between students from public or nonreligious private schools, at least during high school. Distinctions begin to emerge two years after high school. Respondents who attended nonreligious private schools are noticeably less likely to serve through religious organizations or hospitals. They are 13 and 6 percentage points less likely than respondents who attended public schools to participate in volunteer activities through those two types of organizations, respectively. As nonreligious private school students enter young adulthood, we observe that volunteering in hospitals is no different relative to those of public-school students, but the lower propensity to volunteer in religious organizations persists and remains of similar magnitude, 14 percentage points.

\section{Discussion}

\section{Summary of Findings}


We do not find any school-sector differences in the likelihood of volunteering by the time graduates are in the later twenties. However, when we more closely examine types of volunteerism activities, some tendencies previously hidden in the overall volunteerism rates begin to emerge.

The results provide evidence broadly supporting our hypotheses. For instance, the rates of volunteering are certainly high when student volunteering is organized by the Catholic high schools. Moreover, such volunteering typically happens in areas where Catholic organizations are well-represented, such as health care and community centers. However, the Catholic school advantage in volunteering is difficult to sustain into young adulthood. Only Protestant schools are able to maintain relatively higher levels of volunteering into young adulthood. These activities are mainly tied to church and church-related organizations rather than secular organizations. In contrast, volunteerism among students from nonreligious private schools appear similar to those of public schools. Students from both of these sectors appear more likely to volunteer in secular organizations rather than religious organizations.

\section{Interpretation of Findings}

School sector may influence volunteering by connecting students to particular organizational volunteering networks that reflect institutional values and practices common to a sector. For example, the Catholic Church is well represented in health care and community centers, and neighborhood improvement organizations, including Catholic worker houses. The missions of Catholic organizations in the civic sphere often concern the immediate needs of the poor or the sick, which has inspired the emergence of Catholic hospitals, Catholic Relief Services, and so forth (Degeneffe, 2003). Catholic school organizational ties combine with the strong role that Catholic schools play in facilitating student volunteering to shape student 
volunteering types. For many Catholic schools, the volunteering emphasis along with service learning classes are a central expression of the religious mission of the school that is demonstrated by their students' higher rates of overall volunteering in secondary school and volunteering in the health care sector during adulthood (Bryk et al., 1993; Campbell, 2001; Scanlan, 2008).

However, it appears that the Catholic-school advantage in volunteering that is welldocumented in the literature (Wolf 2007) may not persist into adulthood, a finding consistent with other studies (Dill, 2009; Hill \& den Dulk, 2013; Schwartz \& Sikkink, 2014; Sikkink, 2012). We suggest that this finding reflects the organization of volunteering during high school, in which Catholic schools play a strong role in facilitating student volunteering and integrating it into the curriculum. That approach may lead to volunteer fatigue, or a dependence on the school organization, including its social life, to motivate volunteering (Henderson et al., 2012; Jones \& Hill, 2003; Planty et al., 2016). The lack of an avenue to civic life through commitment to other Catholic institutions, including parishes, may also affect overall levels of volunteering for Catholic-school students after secondary school. These students may become disconnected from broader Catholic institutions and social networks that sustain volunteerism behavior (Omoto \& Snyder, 2002; Synder \& Omoto, 2008). Indeed, many students in Catholic schools are not Catholic and it is not uncommon for Catholic students to become disconnected from the Church as they enter adulthood (Cheng et al., 2016; Smith et al., 2014). The ending of secondary school is a significant time of transition among adolescents and volunteerism may dissipate without norms and expectations in new communities to sustain those practices amidst other competing priorities and goals (Jones, \& Hill, 2003; Marks \& Jones, 2004). If such norms and expectations of the communities that Catholic-school students end up joining are weaker than those found in 
Catholic secondary schools from which they left, then it is not surprising that we observe a decrease in volunteerism.

Protestant school students show no tendency toward one volunteering sector, at least during high school. This is surprising given the expectation that strong ties between Protestant schools and churches would channel most volunteering opportunities through churches or church-related organizations. While students remain in Protestant school, we find no evidence for this claim. More likely, Protestant schools follow common models for student volunteering; volunteering in Protestant schools may simply follow scripts familiar to other types of schools, including norms that prioritize soup kitchens, senior citizens, poverty relief, and health care in student volunteering. The emphasis of Protestant schools, that students should experience direct meeting of human needs, can be expressed as well in several of the traditional civic sectors, not only the religious sector.

Most strikingly, we find that Protestant school students in young adulthood primarily volunteer in religious civic organizations - a result that may explain why volunteering rates are sustained into young adulthood (Hill and den Dulk, 2013). Like Park and Smith (2002) and Evans et al. (2013), we find evidence that the involvement of Protestant-school students is particularly strong in the religious civic sphere. The strength of Protestant schools for longerterm effects on volunteering is likely an outcome of the mission and organizational ties of Protestant schools. Religious organizations in civic life quite possibly play a unique and important mediating role between civic life and those who select into Protestant schools. The overall level of civic participation, then, may not increase if Protestant schools and their networks were not available for families that are likely to choose them. The high rates of volunteering among Protestant school students may stem from the unique place of service and 
sacrifice in the school community and associated pathways to civic life through religious organizations. Ties to broader civil society may be fostered through ties to local churches (Campbell \& Putnam, 2011; Driskell et al., 2008; Schwadel, 2005; Wuthnow, 2009).

As hypothesized, we also observed concurrent lower volunteerism rates through political or environmental groups for students from Protestant schools. The assumption of a boundary between spiritual and secular political life together with fears of a potential controversy among parents should the religious mission of the school become closely tied to political engagement, ensures that these schools are not facilitating political volunteering and perhaps discouraging recruitment attempts by political organizations even if they are politically conservative. Yet unlike Protestant-school students, it appears that Catholic-school students are as equally likely to volunteer through political organizations as public school students in young adulthood. These results are consistent with documentation of higher rates of political engagement among Catholic parishes relative to Protestant congregations (Beyerlein \& Chaves, 2003).

Meanwhile, there is little clear-cut evidence for distinctive patterns of volunteering between students from nonreligious private schools and public schools. In fact, differences between these sectors in volunteerism rates across different types of organizations are not only statistically indistinguishable but also substantively small during high school. After high school, it becomes more apparent that both nonreligious private and public schoolers place greater emphasis on volunteering and service through youth or community-service organizations, environmental groups, and political groups-at least in comparison to Protestant schoolers. The nonreligious private schoolers' lack of established ties to church and church-related civic organizations becomes more evident in the young adult years. Dominant orientations to civic life developed in public and nonreligious private schools favor the nonreligious civic sphere. 
Our aim has been to describe volunteerism behavior among individuals from different schooling backgrounds in the U.S. We go beyond prior research in this area by investigating volunteerism longitudinally and detailing the particular kinds of volunteering activity in which people participate. We reiterate that we lack the kind of data that could more definitively test causal relationships between school characteristics and practices, high school civic education, and later volunteering behavior.

Nonetheless, our work sheds light on how to enhance high school civic education programs and goals. We have suggested that school effects on volunteering are channeled and sustained through unique ecologies of school networks, organizations, and cultures. More research into the unique practices of distinctive schools that are aimed at fostering specific civic dispositions — whether it is through requiring and organizing volunteering activities or by some other means — would be valuable. Indeed, requiring volunteering in high school does not necessary lead to sustained volunteering in adulthood (Henderson et al., 2012; Jones \& Hill, 2003; Planty et al., 2016). Perhaps other social norms, habits, and values are necessary to sustain and foster longer-lasting civic dispositions. Thus, we encourage further study of the extent and nature of school practices and organizational ties that may translate into durable links between students and civic life. Answering these questions will be valuable to understand how to promote volunteerism and respond to concerns about religious institutions as well as trends in volunteering and broader participation in civic life. 


\section{References}

Astin, A., Sax, L., \& Avalos, J. (1999). Long-term effects of volunteerism during the undergraduate years. Review of Higher Education, 22(2), 187-202.

Beyerlein, K., \& Chaves, M. (2003). The political activities of religious congregations in the United States. Journal for the Scientific Study of Religion, 42(2), 229-246.

Beyerlein, K., \& Hipp, J. (2006). From Pews to Participation: The effect of congregation activity and context on bridging civic engagement. Social Problems, 53(1), 97-117.

Beyerlein, K., Trinitapoli, J., \& Adler, G. (2011). The effect of religious short-term mission trips on youth civic engagement. Journal for the Scientific Study of Religion, 50(4), 780-795.

Broome, J.P. (2011). Approaching the civic mission of schools: Examining adolescent civic engagement in an alternative learning environment [Doctoral dissertation]. Charlottesville, VA: University of Virginia.

Bryk, A. S., Lee, V. E., \& Holland, P. B. (1993). Catholic Schools and the Common Good. Cambridge, MA: Harvard University Press.

Bureau of Labor Statistics. (2016). Volunteering in the United States - 2015. Washington, DC: US Department of Labor.

Campbell, D.E. (2001). Making democratic education work. In P. Peterson \& D. E. Campbell (Eds.), Charters, vouchers, and public education (pp. 241-267). Washington, DC: Brookings Institution Press.

Campbell, D.E., \& Niemi, R.G. (2016). Testing civics: State-level civic education requirements and political knowledge. American Political Science Review, 110(3), 495-511.

Campbell, D. E., \& Putnam, R. (2011). America's grace: How a tolerant nation bridges its religious divides. Political Science Quarterly, 126(4), 611-640. 
Chawla, L. \& Cushing, D.F. (2007). Education for strategic environmental behavior. Environmental Education Research, 13(4), 437-452.

Cheng, A. (2014). Does homeschooling or private schooling promote political intolerance? Evidence from a Christian university. Journal of School Choice, 8(1), 49-68.

Cheng, A., Trivitt, J.R., \& Wolf, P.J. (2016). School choice and the branding of Milwaukee Private Schools. Social Science Quarterly, 97, 362-375.

Dahlin, B. (2010). A state-independent education for citizenship? Comparing beliefs and values related to civic and moral issues among students in Swedish mainstream and Steiner Waldorf schools. Journal of Beliefs and Values, 31(2), 165-180.

Degeneffe, C.E. (2003). What is Catholic about Catholic Charities? Social Work, 48(3), 374-383. Dill, J.S. (2009). Preparing for Public Life: School Sector and the Educational Context of Lasting Citizen Formation. Social Forces, 87(3), 1265-1290.

Driskell, R.L., Lyon, L. \& Embry, E. (2008). Civic engagement and religious activities: Examining the influence of religious tradition and participation. Sociological Spectrum $28(5), 578-601$.

Evans, J.H., \& Feng, J., (2013). Conservative Protestantism and skepticism of scientists studying climate change. Climatic Change, 121(4), 595-608.

Evans, V., Curtis, D.W., \& Cnaan, R.A. (2013). Volunteering among Latter-Day Saints. Journal for the Scientific Study of Religion, 52(4), 827-841.

Fleming, D. J., Mitchell, W., \& McNally, M. (2014). Can Markets Make Citizens? School Vouchers, Political Tolerance, and Civic Engagement. Journal of School Choice, 8(2), 213-226. https://doi.org/10.1080/15582159.2014.905397 
Giles, D.E., \& Eyler, J. (1994). The theoretical roots of service-learning in John Dewey: Toward a theory of service learning. Michigan Journal of Community Service Learning, 1(1), 7785.

Gill, B., Tilley, C., Whitesell, E., Finucane, M., Potamites, L., \& Corcoran, S. (2018). The impact of Democracy Prep Public Schools on civic participation. Cambridge, MA: Mathematica Policy Research.

Glenn, C. (2012). The myth of the common school. Oakland, CA: Institute for Contemporary Studies press.

Grimm, R., Dietz, N., Foster-Bey, J., Reingold, D., \& Nesbit, R. (2006). Volunteer growth in America: A review of trends since 1974. Washington, DC: Corporation for National and Community Service.

Handy, F., Cnaan, R.A., Hustinx, L., Kang, C., Brudney, J.L., Haski-Leventhal, D., ... , \& Zrinscak, S. (2010). A cross-cultural examination of student volunteering: Is it all about resume-building? Nonprofit and Voluntary Sector Quarterly, 39(3), 498-523.

Hart, D., Donnelly, T.M., Youniss, J., Atkins, R. (2007). High school community service as a predictor of adult voting and volunteering. American Educational Research Journal, 44(1), 197-219.

Henderson, A., Brown, S.D., Pancer, S.M. (2012). Political and social dimensions of civic engagement: The impact of compulsory community service. Politics and Policy, 40(1), 93-130.

Hill, J., \& Den Dulk, K. (2013). Religion, Volunteering, and Educational Setting: The Effect of Youth Schooling Type on Civic Engagement. Journal for the Scientific Study of Religion, 52(1), 179-197. 
Ingels, S.J., Pratt, D.J., Alexander, C.P., Jewell, D.N., Lauff, E., Mattox, T.L., Wilson, D., \& Christopher, E. (2014). Education Longitudinal Study of 2002 (ELS:2002): Third followup data file documentation. Washington, DC: National Center for Education Statistics, U.S. Department of Education.

Jones, S.R., \& Hill K.E. (2003). Understanding patterns of commitment. The Journal of Higher Education, 74(5), 516-539.

Justice, B. \& Macleod, C. (2016). Have a little faith: Religion, democracy, and the American Public School. Chicago, IL: University of Chicago Press.

McFarland, D.A. \& Thomas, R.J. (2006). Bowling Young: How Youth Voluntary Associations Influence Adult Political Participation. American Sociological Review 71, 401-425.

Marks, H.M., \& Jones, S.R. (2004). Community service in the transition: Shifts and continuities in participation from high school to college. The Journal of Higher Education, 75(3), $307-339$.

Marks, H.M., \& Kuss, P. (2001). Socialization for citizenship through community service: Disparities in participation among US high school students. Sociological Focus, 34(4), 377-398.

Mehta, J. \& Fine, S. (2019). In search of deeper learning: The quest to remake the American high school. Cambridge, MA: Harvard University Press.

Moe, T.M. (2011). Special interest: Teachers unions and America's public schools. Washington, DC: Brookings Institution Press.

Omoto, A.M., Snyder, M. (2002). Considerations of community: The context and process of volunteerism. American Behavioral Scientist, 45(5), 846-867. 
Park, J., \& Smith, C. (2000). “To Whom Much Has Been Given...”: Religious Capital and Community Volunteerism among Churchgoing Protestants. Journal for the Scientific Study of Religion, 39(3), 272-286.

Planty, M., Bozick, R., \& Regnier, M. (2006). Helping because you have to or helping because you want to? Sustaining participation in service work from adolescence through young adulthood. Youth and Society, 38(2), 177-202.

Putnam, Robert. (2000). Bowling Alone: The Collapse and Revival of American Community. New York, NY: Simon and Schuster Paperbacks.

Riedel, E. (2002). The impact of high school community service programs on students' feelings of civic obligation. American Politics Research, 30(5), 499-527.

Scanlan, M. (2008). The grammar of Catholic schooling and radically "Catholic" schools. Catholic Education: A Journal of Inquiry and Practice, 12(1), 25-54.

Schwadel, P. (2005). Individual, congregational, and denominational effects on church members' civic participation. Journal for the Scientific Study of Religion, 44(2), 159-171.

Schwartz, J., \& Sikkink, D. (2017). The lasting impact of high school on giving and volunteering in the U.S. Notre Dame, IN: Cardus Religious Schools Initiative, University of Notre Dame.

Sikkink, D. (2012). Religious school differences in school climate and academic mission: A descriptive overview of school organization and student outcomes. Journal of School Choice, 6(1), 20-39.

Sikkink, D. (2014). What is your major? Occupational trajectories of graduates of religious schools. Notre Dame, IN: Cardus Religious Schools Initiative, University of Notre Dame. 
Smith, C., Christoffersen, K., Davidson, H., \& Herzog, P.S. (2009). Lost in transition: The dark side of emerging adulthood. New York, NY: Oxford University Press.

Smith, C., Longest, K., Hill, J., Christoffersen, K. (2014). Young Catholic America: Emerging adults in, out of, and gone from the Church. New York, NY: Oxford University Press.

Smith, C., \& Sikkink, D. (1999). Is private schooling privatizing? First Things, 92, 16-20.

Snyder, M., \& Omoto, A.M. (2008). Volunteerism: Social issues perspectives and social policy implications. Social Issues and Policy Review, 2(1), 1-36.

Uecker, J.E. (2009) Catholic schooling, Protestant schooling, and religious commitment in young adulthood. Journal for the Scientific Study of Religion, 48(2),353-367.

Wolf, P.J. (2007). Civics Exam: Schools of Choice Boost Civic Values. Education Next, 7(3), $66-72$. 
Figure 1: Overall Volunteerism Rates by School Sector and ELS Wave

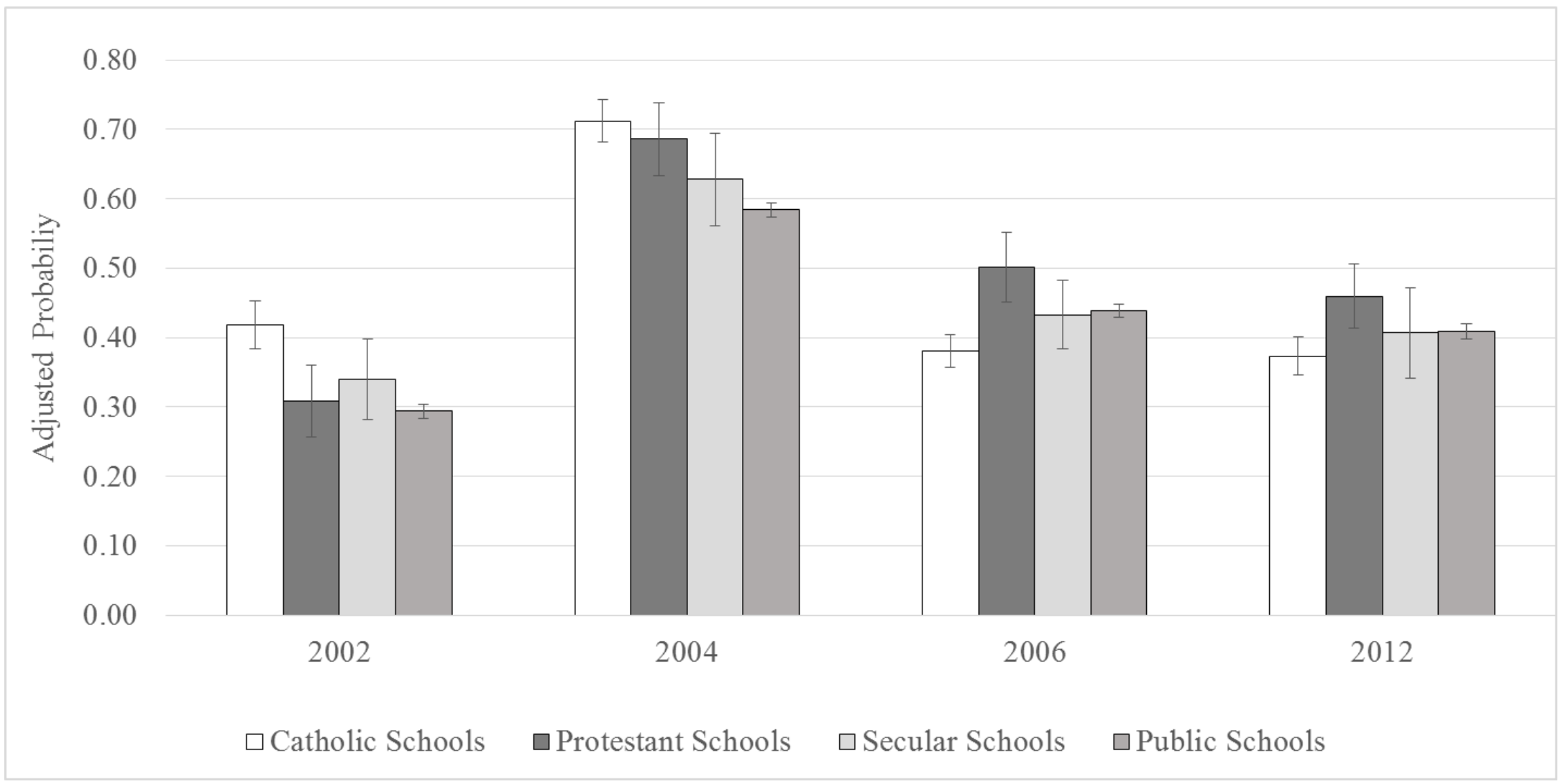

Note: Predicted probabilities of participating in volunteer work are adjusted for control variables listed in Table 2; 95 percent confidence intervals shown. 
Table 1: Volunteerism Rates

\begin{tabular}{cc}
\hline Type of Volunteering & $\begin{array}{c}\text { Percentage of Sample } \\
\text { Participating }\end{array}$ \\
\hline
\end{tabular}

First Wave (Tenth Grade Year)

Any Volunteering 32.0

Second Wave (Twelfth Grade Year)

Any Volunteering $\quad 57.4$

Youth or Community-Service Organizations ${ }^{\mathrm{a}} \quad 35.1$

Political Clubs or Organizations $\quad 4.4$

Churches or Church-related Groups $\quad 21.1$

Community Centers or Neighborhood Groups $\quad 11.3$

Hospitals, Nursing Homes, Retirement Communities 8.7

Environmental Groups $\quad 3.2$

Third Wave (Two Years after Twelfth Grade)

Any Volunteering $\quad 40.9$

Youth or Community-Service Organizations 25.2

Political Clubs or Organizations $\quad 5.6$

Churches or Church-related Groups $\quad 18.9$

Community Centers or Civic Groups $\quad 15.0$

Hospitals, Nursing Homes, Retirement Communities 6.9

Environmental Groups $\quad 3.4$

Fourth Wave (Eight Years after Twelfth Grade)

Any Volunteering 39.2

Youth or Community-Service Organizations 23.5

Political Clubs or Organizations $\quad 1.8$

Churches or Church-related Groups $\quad 14.6$

Community Centers or Civic Groups $\quad 12.9$

Hospitals, Nursing Homes, Retirement Communities $\quad 4.2$

Environmental Groups 2.0

Note. Sampling weights used to compute percentages. ${ }^{a}$ For example, Little League, Scouts, Big Brother/Big Sister, Key Club and other community service groups based in schools or serving youth. 
Table 2: Summary Statistics for Independent Variables

\begin{tabular}{|c|c|c|}
\hline & Mean & $\begin{array}{c}\text { Standard } \\
\text { Deviation }\end{array}$ \\
\hline \multicolumn{3}{|l|}{ Respondent Characteristics in High School (Waves 1 and 2) } \\
\hline \multicolumn{3}{|l|}{ School Sector } \\
\hline Public School & 0.92 & 0.27 \\
\hline Catholic School & 0.04 & 0.20 \\
\hline Protestant School & 0.02 & 0.14 \\
\hline Nonreligious Private School & 0.02 & 0.13 \\
\hline Male & 0.50 & 0.50 \\
\hline \multicolumn{3}{|l|}{ Racial Background } \\
\hline White & 0.60 & 0.49 \\
\hline Black & 0.14 & 0.35 \\
\hline Hispanic & 0.16 & 0.27 \\
\hline Asian & 0.04 & 0.20 \\
\hline Other Race & 0.05 & 0.22 \\
\hline \multicolumn{3}{|l|}{ Mother's Education } \\
\hline Less than High School & 0.13 & 0.34 \\
\hline High School & 0.28 & 0.45 \\
\hline Some College & 0.10 & 0.30 \\
\hline Two-Year Degree & 0.24 & 0.43 \\
\hline Four-Year Degree & 0.17 & 0.37 \\
\hline Post-Baccalaureate Degree & 0.08 & 0.27 \\
\hline \multicolumn{3}{|l|}{ Family Income } \\
\hline Less than $\$ 20,000$ & 0.15 & 0.36 \\
\hline$\$ 20,001$ to 25,000 & 0.07 & 0.25 \\
\hline$\$ 25,001$ to 35,000 & 0.12 & 0.33 \\
\hline$\$ 35,001$ to 50,000 & 0.20 & 0.40 \\
\hline$\$ 50,001$ to 75,000 & 0.21 & 0.41 \\
\hline$\$ 75,001$ to 100,000 & 0.13 & 0.34 \\
\hline More than $\$ 100,000$ & 0.13 & 0.33 \\
\hline Math Test Scores & 50.00 & 10.00 \\
\hline Reading Test Scores & 50.00 & 10.00 \\
\hline Volunteered in $10^{\text {th }}$ Grade (baseline year of ELS:02) & 0.29 & 0.46 \\
\hline \multicolumn{3}{|l|}{ School Urbanicity } \\
\hline Urban & 0.30 & 0.46 \\
\hline Suburban & 0.50 & 0.50 \\
\hline Rural & 0.20 & 0.40 \\
\hline \multicolumn{3}{|l|}{ Religious Background } \\
\hline Catholic & 0.34 & 0.47 \\
\hline Evangelical Protestant & 0.40 & 0.40 \\
\hline Mainline Protestant & 0.16 & 0.37 \\
\hline Other Religion & 0.07 & 0.25 \\
\hline Atheist/Agnostic & 0.03 & 0.18 \\
\hline
\end{tabular}

Frequency of Attendance at Religious Services 
Never

$0.17 \quad 0.38$

Rarely

0.13

0.34

Sometimes

0.24

0.43

Frequently

Respondent Characteristics during Post-Secondary Years (Wave 3)

Earned a High School Diploma, GED, or Equivalent

Post-Secondary Institution Enrollment

Public 4-Year

0.29

0.45

Private 4-Year

0.27

0.45

Public 2-Year

0.14

0.34

Private 2-Year

0.27

0.44

Not Enrolled in Post-Secondary Education Program

0.03

0.18

Respondent Characteristics in Young Adulthood (Wave 4)

Educational Attainment

Less than High School

0.03

0.17

High School

0.13

0.33

Some College

0.51

0.50

Bachelor's Degree

0.27

0.44

Post-Baccalaureate Degree

0.07

0.25

Log of Family Income (\$)

9.22

3.95

Note: Sampling weights used to compute statistics. 
Table 3: Type of Volunteering from Adolescence to Young Adulthood

\begin{tabular}{|c|c|c|c|c|c|c|}
\hline & \multicolumn{6}{|c|}{ Dependent Variable (Type of Volunteering) } \\
\hline & (1) & $(2)$ & (3) & (4) & $(5)$ & $(6)$ \\
\hline & $\begin{array}{l}\text { Political Clubs } \\
\text { or Organizations }\end{array}$ & $\begin{array}{c}\text { Religious or } \\
\text { Spiritual Groups }\end{array}$ & $\begin{array}{l}\text { Hospitals, } \\
\text { Nursing or } \\
\text { Retirement } \\
\text { Homes } \\
\end{array}$ & $\begin{array}{c}\text { Community } \\
\text { Centers or } \\
\text { Neighborhood } \\
\text { Associations }\end{array}$ & $\begin{array}{c}\text { Environmental } \\
\text { Groups }\end{array}$ & $\begin{array}{c}\text { Youth or } \\
\text { Community- } \\
\text { Service } \\
\text { Organizations } \\
\end{array}$ \\
\hline \multicolumn{7}{|c|}{ Wave $2 ; 2004 ; 12 t \overline{\text { grade year }}$} \\
\hline Catholic & $\begin{array}{c}-0.036^{* * *} \\
(0.014)\end{array}$ & $\begin{array}{c}0.016 \\
(0.023)\end{array}$ & $\begin{array}{c}0.055^{* * * *} \\
(0.018)\end{array}$ & $\begin{array}{c}0.040 * * \\
(0.019)\end{array}$ & $\begin{array}{c}0.001 \\
(0.012)\end{array}$ & $\begin{array}{c}0.018 \\
(0.029)\end{array}$ \\
\hline Protestant & $-0.044 * *$ & 0.014 & 0.014 & 0.041 & 0.008 & $-0.118 * *$ \\
\hline Nonreligious & $\begin{array}{c}(0.020) \\
0.015 \\
(0.019)\end{array}$ & $\begin{array}{c}(0.049) \\
-0.009 \\
(0.036)\end{array}$ & $\begin{array}{c}(0.029) \\
-0.016 \\
(0.031)\end{array}$ & $\begin{array}{c}(0.030) \\
0.032 \\
(0.030)\end{array}$ & $\begin{array}{c}(0.017) \\
-0.004 \\
(0.017)\end{array}$ & $\begin{array}{c}(0.047) \\
0.010 \\
(0.038)\end{array}$ \\
\hline \multicolumn{7}{|c|}{ Wave 3; 2006; Two years after 12th grade } \\
\hline Catholic & $\begin{array}{c}0.007 \\
(0.017)\end{array}$ & $\begin{array}{l}-0.017 \\
(0.025)\end{array}$ & $\begin{array}{c}0.021 \\
(0.020)\end{array}$ & $\begin{array}{l}-0.008 \\
(0.026)\end{array}$ & $\begin{array}{l}-0.017 \\
(0.017)\end{array}$ & $\begin{array}{l}-0.016 \\
(0.029)\end{array}$ \\
\hline Protestant & $\begin{array}{l}-0.034 \\
(0.035)\end{array}$ & $\begin{array}{c}0.133 * * * \\
(0.039)\end{array}$ & $\begin{array}{c}0.035 \\
(0.026)\end{array}$ & $\begin{array}{l}-0.071 * \\
(0.039)\end{array}$ & $\begin{array}{c}-0.086^{* * *} \\
(0.025)\end{array}$ & $\begin{array}{c}0.026 \\
(0.044)\end{array}$ \\
\hline Nonreligious & $\begin{array}{c}0.049 \\
(0.032)\end{array}$ & $\begin{array}{c}-0.132 * * * \\
(0.046)\end{array}$ & $\begin{array}{c}-0.060 * * \\
(0.028)\end{array}$ & $\begin{array}{c}0.012 \\
(0.039)\end{array}$ & $\begin{array}{c}0.021 \\
(0.027)\end{array}$ & $\begin{array}{c}0.048 \\
(0.044)\end{array}$ \\
\hline \multicolumn{7}{|c|}{ Wave 4; 2012; Eight years after 12th grade } \\
\hline Catholic & $\begin{array}{l}-0.002 \\
(0.013)\end{array}$ & $\begin{array}{l}-0.027 \\
(0.036)\end{array}$ & $\begin{array}{l}0.031 * \\
(0.019)\end{array}$ & $\begin{array}{l}-0.048 \\
(0.032)\end{array}$ & $\begin{array}{l}-0.021 \\
(0.015)\end{array}$ & $\begin{array}{l}-0.016 \\
(0.036)\end{array}$ \\
\hline Protestant & $\begin{array}{c}-0.050 * * \\
(0.023)\end{array}$ & $\begin{array}{c}0.161 * * * \\
(0.043)\end{array}$ & $\begin{array}{c}0.030 \\
(0.023)\end{array}$ & $\begin{array}{l}-0.044 \\
(0.034)\end{array}$ & $\begin{array}{l}-0.052 * \\
(0.025)\end{array}$ & $\begin{array}{l}-0.064 \\
(0.045)\end{array}$ \\
\hline Nonreligious & $\begin{array}{c}0.024 \\
(0.016)\end{array}$ & $\begin{array}{c}-0.140 * * * \\
(0.046)\end{array}$ & $\begin{array}{c}0.011 \\
(0.023)\end{array}$ & $\begin{array}{l}-0.058 \\
(0.040)\end{array}$ & $\begin{array}{l}-0.020 \\
(0.022)\end{array}$ & $\begin{array}{c}0.024 \\
(0.048)\end{array}$ \\
\hline
\end{tabular}

Notes: Marginal effects are shown. Samples in each wave are restricted to those who volunteered in that wave. Omitted category represents respondents who attended a public high school. Sampling weights included. Robust standard errors clustered at the school level are shown in parenthesis. $* * * \mathrm{p}<0.01, * * \mathrm{p}<0.05, * \mathrm{p}<0.1$ 